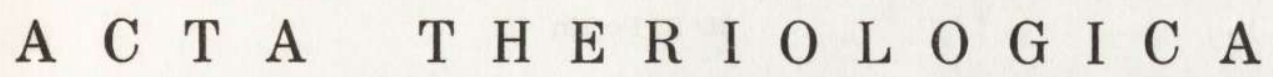

VOL., 20, 15: 167-174.

June, 1975

\author{
M. R. PERRIN*
}

\section{Trap Deaths}

[With 6 Tables]

\begin{abstract}
Investigations of trap mortality were made on adjacent populations of Microtus agrestis Linnae us, 1761 and Clethrionomys glareolus (S c hreber, 1780) during 1969-1970. Trap deaths are not associated with repeated capture, but with capture late in a trapping occasion. Voles of all trappable weights are affected. The main causes of trap mortality appear to be extreme temperatures and rainfall. The latter causes the trap contents to become wet, which is thought to affect the thermoregulation of confined voles, particularly at low temperatures. There appears to be little correlation between population density and trap mortality.
\end{abstract}

\section{INTRODUCTION}

All trapping programmes represent a form of interference with the population under study. Most effects are transient or fairly trivial, but trap deaths are an extreme form of interference, are permanent, and can have an unacceptably high effect on the population, to the extent that the nature of the phenomenon being studied is grossly and irreversibly distorted.

It is therefore desirable when estimating small mammal populations by live trapping to keep trap deaths to a minimum. Trap deaths cause difficulty in the interpretation of capture data for population estimates, unless this factor is allowed for, such as in Jolly's (1965) stochastic method. Even so, these deaths have an effect upon the population in terms of reproductive potential, movements and probably other population processes. As stated by Shaw \& Milner (1967) this form of interference could be particularly critical with small overwintering populations which provide the nucleus for subsequent breeding.

* Present address: Environmental Research Branch, Whiteshell Nuclear Research Establishment, Atomic Energy of Canada Limited, Pinawa, Manitoba, Canada ROE $1 \mathrm{LO}$. 
During population studies of the voles, Microtus agrestis, and Clethrionomys glareolus, during 1969-1970, data were collected upon trap mortality. These are reported and suggestions are made as to their possible cause. Methods for the reduction of trap mortality in future studies are presented.

\section{METHODS}

Trapping occurred regularly at approximately monthly intervals from October 1969 to September 1970. Each census consisted of a capture, mark and release programme over four consecutive nights of trapping, using Longworth live traps. The trapping grid consisted of eight rows and twelve lines. Trapping points were $10 \mathrm{~m}$ apart and two traps were set at each point. Traps were prepared with adequate quantities of oats for food, and dry hay for bedding; when set they were baited with some oats at the tunnel entrance of the trap. Records of daily rainfall and minimum and maximum temperatures were collected from the Agricultural Research Station at Exmouth, only a few miles east of the study area at Mamhead. The trapping site was a young larch (Larix decidua) plantation with thick growths of grasses in some areas, bramble and nettles in others, and with a few large oaks (Quercus robur); a more detailed account is given by Perrin (1971).

\section{RESULTS}

Trap deaths were not uncommon, and occurred in all months of the year in C. glareolus, and in all months except October and November in $M$. agrestis (Table 1). During the study there were 4,027 captures and 83 trap deaths, or approximately two per cent.

Table 1

Occurrence of trap deaths.

\begin{tabular}{|c|c|c|c|c|c|c|c|c|c|c|c|}
\hline Oct. & Nov. & Dec. & Jan. & Feb. & Mar. & April & May & Jun. & Jul. & Aug. & Sept. \\
\hline 0 & 0 & 1 & 7 & 3 & $\begin{array}{c}\text { Microtus } \\
3\end{array}$ & $\underset{9}{\text { agrest }}$ & is 2 & 11 & 1 & 2 & 1 \\
\hline 5 & 2 & 1 & 2 & $\begin{array}{l}\text { Clet } \\
6\end{array}$ & $\begin{array}{l}\text { hrionom } \\
2\end{array}$ & ${ }_{4}^{2 y s}$ glar & $\begin{array}{c}\text { eolus } \\
2\end{array}$ & 6 & 1 & 9 & 3 \\
\hline 5 & 2 & 2 & 9 & 9 & ${ }_{5}^{\mathrm{To}}$ & ${ }_{13}$ & 4 & 17 & 2 & 11 & 4 \\
\hline
\end{tabular}

Variation in trap mortality was large between months, but there is little to suggest a seasonal pattern, although deaths were fewer in late autumn than other times. Variations in mortality were not always similar for both species. Greatest trap mortality occurred in January, April and June in $M$. agrestis and in February, June and August in C. glareolus.

When the effect of day of capture upon trap deaths is examined, (Table 2 ), it is evident that more voles die later in the four-day census period than would be expected.

The tendency is marked, and similar for both species; over two thirds 
of trap deaths occurred during the third and fourth nights of capture in both species. (On the fourth night significantly more $M$. agrestis died than were expected to die: $\chi^{2}=8.10$, i.e. $1.0 \%$ level of significance. On the third and fourth nights more $C$. glareolus died than were expected to die: $\chi^{2}=5.13$, i.e. $5.0 \%$ level of significance).

This indicates that voles captured later in the census period were liable to heavier mortality, but gives little information as to the cause. Therefore, the number of deaths was considered in relation to the number of previous trap entries during the four day census period (Table 3).

This indicates that over two thirds of the deaths occur to voles that had not or only once been previously captured, during the four day census. Therefore previous trap confinement, and the associated physiological stress, is unlikely to be the major cause of trap mortality, but may be a contributary factor. It therefore seems likely that it is changed conditions within the occupied traps that cause the deaths.

Table 2

Effect of day of capture upon trap mortality.

\begin{tabular}{lccccc}
\hline & \multicolumn{2}{c}{ Microtus } & \multicolumn{3}{c}{ Clethrionomys glareolus } \\
Day & Deaths & $\%$ deaths per day & Day & Deaths & $\%$ deaths per day \\
\hline 1 & 5 & 12.50 & 1 & 8 & 18.60 \\
2 & 8 & 20.00 & 2 & 3 & 6.98 \\
3 & 8 & 20.00 & 3 & 14 & 32.56 \\
4 & 19 & 47.50 & 4 & 18 & 41.86 \\
\hline
\end{tabular}

Table 3

Effect of previous capture upon trap mortality.

\begin{tabular}{cccccr}
\hline \multirow{2}{*}{$\begin{array}{c}\text { Previous } \\
\text { captures }\end{array}$} & Microtus agrestis & \multicolumn{3}{c}{ Clethrionomys glareolus } \\
\hline 0 & Deaths & $\%$ & $\begin{array}{c}\text { Previous } \\
\text { captures }\end{array}$ & Deaths & $\%$ \\
1 & 15 & 37.50 & 0 & 23 & 53.49 \\
2 & 13 & 32.50 & 1 & 12 & 27.91 \\
3 & 5 & 12.50 & 2 & 6 & 13.95 \\
& 7 & 17.50 & 3 & 2 & 4.65 \\
\hline
\end{tabular}

The effects of weather upon trap mortality are considered. During the study, 83 voles died in traps ( $40 \mathrm{M}$. agrestis and $43 \mathrm{C}$. glareolus) over the forty eight trap nights, an average of 1.73 deaths per night. Of the forty-eight nights of trapping eighteen were wet, and only eleven had more than $1.0 \mathrm{~mm}$ of rainfall. On these eleven occasions, 22 voles died (11 M. agrestis and 11 C. glareolus), and therefore an average of 2.0 voles diect per night. This suggests that rainfall does increase trap mortality but not 
significantly so. Thus if trap dampness is important in causing trap deaths then rainfall is probably not the only cause, and ground water, dew and so on are probably involved. The effect of temperature upon trap mortality was also examined (Table 4).

Temperatures at or below freezing point increase trap mortality but not markedly so; at temperatures between 0.0 and $4.4^{\circ} \mathrm{C}$, trap mortality is low. Temperatures above $18.3^{\circ} \mathrm{C}$ significantly increase trap mortality (at the $1 \%$ level of significance: $\chi^{2}=6.94$ ). These results indicate that rainfall and extremes of temperature increase trap mortality in voles: both species were affected similarly.

The relationship between trap mortality and body weight can be seen from investigation of Table 5 .

Table 4

The effect of temperature upon trap mortality.

\begin{tabular}{ccc}
\hline Temperature ${ }^{\circ} \mathrm{C}$ & $\begin{array}{c}\text { Frequency } \\
\text { of occurrence }\end{array}$ & Death rate \\
\hline$<7.2$ & $52.1 \%$ & 1.72 \\
$\leq 4.4$ & $39.6 \%$ & 1.53 \\
$>0.0$ & $22.9 \%$ & 2.00 \\
$>18.3$ & $25.0 \%$ & 2.67 \\
\hline
\end{tabular}

(Overall death rate for all nights 1.73 deaths/night.)

Table 5

The relationship between body weight and trap mortality.

\begin{tabular}{|c|c|c|c|c|}
\hline \multirow{2}{*}{ Weight in gms. } & \multirow{2}{*}{\multicolumn{2}{|c|}{$\begin{array}{c}\text { Animals dead in traps } \\
\text { Deaths }\end{array}$}} & \multicolumn{2}{|c|}{ Animals captured alive } \\
\hline & & & Numbers & $\%$ \\
\hline \multicolumn{5}{|c|}{ Microtus agrestis } \\
\hline$<10.2$ & 3 & 7.50 & 0 & 0.00 \\
\hline $10.2-15.2$ & 1 & 2.50 & 40 & 5.34 \\
\hline $15.2-20.2$ & 5 & 12.50 & 194 & 25.87 \\
\hline $20.2-25.2$ & 19 & 47.50 & 236 & 31.48 \\
\hline $25.2-30.2$ & 11 & 27.50 & 185 & 24.68 \\
\hline$>30.2$ & 1 & 2.50 & 94 & 12.54 \\
\hline \multicolumn{5}{|c|}{ Clethrionomys glareolus } \\
\hline$<10.2$ & 1 & 2.33 & 6 & 0.81 \\
\hline $10.2-15.2$ & 11 & 25.58 & 98 & 13.21 \\
\hline $15.2-20.2$ & 21 & 48.84 & 342 & 46.09 \\
\hline $20.2-25.2$ & 6 & 13.95 & 215 & 28.97 \\
\hline $25.2-30.2$ & 4 & 9.30 & 76 & 10.24 \\
\hline$>30.2$ & 0 & 0.00 & 5 & 0.67 \\
\hline
\end{tabular}

The distribution of trap deaths according to body weight is different in C. glareolus and M. agrestis. In C. glareolus there is a tendency for lower weighted voles to be more evident in the trap death figures than 
would be expected from the population structure (significant at the $1 \%$ level of significance). This may be indicative of reduced resistance to the above mentioned factors by young voles. However there is a slight tendency for larger $M$. agrestis to be more susceptible to trap deaths (significant at the $1 \%$ level of significance). The reason for this is unclear. (Of forty $M$. agrestis trap deaths, twenty-two were males, fourteen females and four unsexed juveniles. There were thirty-three adults and seven sub-adults. Of the forty three $C$. glareolus trap deaths, twenty one were males, eighteen were females, and four unsexed juveniles. There were twenty three adults and twenty sub-adults.)

P l a t t (1968) suggested the differences in rate of seasonal trap mortality might be an indication to the degree of stress upon animals at different densities. Table 6 compares population density estimated by Jolly's (1965) stochastic method with trap mortality for the two vole populations under consideration.

Table 6

Population density (upper line) and trap mortality (lower line).

\begin{tabular}{|c|c|c|c|c|c|c|c|c|c|c|c|}
\hline Oct. & Nov. & Dec. & Jan. & Feb. & Mar. & April & May & Jun. & Jul. & Aug. & Sept. \\
\hline \multicolumn{12}{|c|}{ Microtus agrestis } \\
\hline 41 & 53 & 90 & 105 & 135 & 115 & 92 & 78 & 110 & 74 & 103 & 84 \\
\hline 0 & 0 & 1 & 7 & 3 & 3 & 9 & 2 & 11 & 1 & 2 & 1 \\
\hline \multicolumn{12}{|c|}{ Clethrionomys glareolus } \\
\hline 69 & 91 & 76 & 88 & 103 & 76 & 54 & 72 & 66 & 76 & 98 & 97 \\
\hline 5 & 2 & 1 & 2 & 6 & 2 & 4 & 2 & 6 & 1 & 9 & 3 \\
\hline
\end{tabular}

For $M$. agrestis there is some indication of an increase in trap mortality with population density, but this is not so for C. glareolus. The effect if present is thought to be small, and is probably only a contributary factor to and not the main cause of trap deaths. Whether stress is associated with increased density for these populations is not known. Since no accurate figures are available for population mortality, this parameter cannot be plotted against trap mortality; the seasonal peaks may show some correlation. It should be noted that when population numbers are high traps are occupied more frequently, presuming equal trappability.

\section{DISCUSSION}

Several hypotheses have been put forward to account for trap mortality. C hit ty (1937) suggested that failure to feed whilst confined, or loss of energy due to escape attempts may be important. Oats and hay were placed in the traps in this study because both species eat them well 
in the laboratory, and they are cheap and convenient. In the field, however, bait was not always consumed; this might be due to the food being "unsuitable or to a blocking of normal feeding induced by the "stress" of capture. When live trapping shrews special attention should be paid to providing sufficient live food, e.g. mealworms. Occasionally animals in traps were found damaged owing to attempted escape.

C orke (1967) found a correlation between trap deaths and damp bedding and S h a w \& Milner (1967) suggested that traps covered with insulating material reduced trap mortality, because they excluded water rather than preventing heat loss. Iverson \& Turner (1969) have described an undersnow shelter which is effective in providing low-mortality-rate captures under severe winter conditions. Mille r \& Get z (1968) have used insulated tubes inside traps to reduce trap mortality, and the method is effective at temperatures of -5 to $-10^{\circ} \mathrm{C}$. Ferns (1969) found that trap deaths were associated with the wet interiors of traps, and indicated that the wet interiors and bedding was often not due to heavy rainfall, but to permanent ground water and heavy dew; urine and faeces may be contributary factors. High humidity or damp nesting material inside traps may affect the insulation properties of the fur of mammals by increasing their thermal conductivity. This would be caused by the hairs adhering together and preventing the retention of a layer of static air about the animals body, thus causing body temperature to fall. In this respect low temperature is also important.

However it is thought that high humidity in traps is more important than low temperatures in causing trap deaths. If low temperature "per se" were important in causing trap mortality, higher numbers of deaths would have occurred in late autumn and winter.

Trap deaths due to overheating are not uncommon in summer months; they can be reduced by placing traps under cover or in shade.

Chit ty (1959) has shown that trap confinement can cause physiological stress. Platt (1968) subsequently suggested that differences in rate of seasonal trap mortality might be an indication to the degree of stress upon animals at different populations densities. Ferns (1969) argued that Platt has only demonstrated that trap mortality is higher when mortality in the population is high and vice versa, and that no evidence is presented to suggest that "stress " is the cause of the mortality in any of the cases. Many might argue that stress may well increase with density, and possibly lead to increased mortality, and thus the argument becomes circular. Results presented in this paper suggest that there is little to support a relationship between population density and trap mortality, and hence a relationship with stress appears untenable.

Andrzejewski \& Wrocławek (1961) suggested that trap mor- 
tality is higher in the migrating part of populations of Apodemus agrarius, A. flavicollis and Clethrionomys glareolus. They indicated that several trap deaths occurred to mice previously uncaptured but of adult weights. In this study however the number of trap deaths occurring to unmarked animals was not markedly different from their occurrence within the whole population. It may be that differences in trapping pattern, season, species occurrence and relative abundance, and population density caused fewer migrants to be present or captured than in the study of Andrzejewski \& Wrocławek (1961).

Voles captured late in a census period are liable to heavier mortality than voles captured earlier in the same capture period. However since most deaths occur to voles that have not, or only once been captured previously in a given trapping period, it appears that it is the changed conditions within the trap, e.g. damp bedding, which cause the deaths, and not physiological stress associated with repeated capture.

It appears that rainfall, freezing temperatures and direct exposure of the trap to the sun's radiation causing overheating are the major causes of trap deaths. These are probably modified by interacting climatic factors; inadequate or inappropriate food, or the exhaustion of food in the trap; stress, exhaustion from attempted escape; ground water, dew, and condensation; urination and defaecation within the trap, and the compacting of bedding. However, only detailed experimental work aimed specifically at determining the causes of trap mortality with reference to the above mentioned factors will produce explicit answers.

Trap deaths can be reduced by observing the following procedures. Place dry hay in the nest-box of the trap and if it becomes soddened replace it. Sufficient food, appropriate to diet of the species to be trapped, should also be placed in the nest-box. If trapping for shrews, "mouse excluders « should be used and the trap baited with mealworms. Traps should be waterproofed and insulated (see Shaw \& Milner, 1967), particularly in winter. Shelters should be used when trapping under snow (I vers o n \& Turner, 1969). In summer, traps should be set under cover or in shade to prevent overheating of captured animals. After use, traps should be thoroughly cleaned, and repaired - to eliminate any ragged edges that might damage future captures. If rodents only are required a small metal tube can be inserted in the wall of the nest-box of sufficient diameter to allow shrews to escape but to retain rodents ( $\mathrm{J} \mathrm{e}-$ w e 11, personal communication).

Acknowledgements: I wish to express my thanks, gratitude and appreciation to Prof. L. A. Harvey, Prof. J. Webster, and Prof. D. Nichols for the opportunity to work in their department, and Mr. I. J. Linn under whose supervision this work was carried out.

The study was conducted during the tenure of an S.R.C. research studentship. 


\section{REFERENCES}

1. Andrzejewski R. \& Wroclawek H., 1961: Mortality of small rodents in traps as an indication of the diminished resistance of the migrating part of a population. Bull. Acad. Pol. Sci. Cl. II Sér Sci. biol. 11: 491-492.

2. Chitty D., 1937: A ringing technique for small mammals. J. Anim. Ecol. 6: $36-53$.

3. Chitty D., 1959: A note on shock disease. Ecology 40: 728-731.

4. Corke D., 1967: The deaths of small mammals in live-traps. J. Zool., Lond. 153: 552.

5. F e rns P. N., 1969: Energy flux in a population of field voles, Microtus agrestis hirtus (B ell a m y, 1839) (Muridae). Ph. D. Thesis. University of Exeter.

6. Iverson S. L. \& Turner B. N., 1969: Under-snow shelter for small mammal trapping. J. Wildl. Mgmt. 33: 722-723.

7. Jo11y G. M., 1965: Explicit estimates from capture-recapture data with both death and immigration-stochastic model Biometrika 52: 225-247.

8. Miller D. H. \& Getz L. L., 1968: A method to reduce winter trap mortality. J. Mammal. 49: 147.

9. Perrin M. R., 1971: Exploratory behaviour as related to trapping results and population estimation in the vole, Microtus agrestis hirtus (B ell a m y, 1839). Ph. D. Thesis. University of Exeter.

10. Platt, A. P., 1968: Differential trap mortality as a measure of stress during times of population increase and decrease. J. Mammal. 49: 331-335.

11. Shaw M. W. \& Milner C., 1967: The use of insulating covers for Longworth traps. J. Zool., Lond. 153: 546-551.

Âccepted, July 24, 1974.

Department of Biological Sciences,

University of Exeter,

Devon, England.

M. R. PERRIN

SMIERTELNOSC W PUEAPKACH

\section{Streszczenie}

Badano śmiertelność dwóch gatunków gryzoni; nornicy rudej Clethrionomys glareoius ( $\mathrm{S} \mathrm{chreber,1970)} \mathrm{i} \mathrm{nornika} \mathrm{burego} \mathrm{Microtus} \mathrm{agrestis} \mathrm{(} \mathrm{L}$ in na e u s, 1761) w pułapkach żywołownych typu Longworth. Smiertelność gryzoni w pułapkach obserwowano w ciągu całego roku, niezależnie od sezonu (Tabela 1). W okresie czterodniowych serii połowów śmiertelność znamiennie wzrasta pod koniec tego okresu. Śmiertelność w pułapce nie zależy od wcześniejszych złowień (Tabela 3) i obejmuje gryzonie wszystkich klas ciężaru ciała (Tabela 5). Deszcze oraz skrajne (niskie lub wysokie) temperatury wpływają na zwiększenie śmiertelności gryzoni w pułapkach (Tabela 4). Okazuje się, że istnieje niewielka korelacja między śmiertelnością gryzoni w pułapkach a liczebnością populacji (Tabela 6). 